\title{
BIODRYING AS A BIOLOGICAL PROCESS TO DIMINISH MOISTURE IN GARDENING AND
}

\section{HARVEST WASTES}

\section{F. J. Colomer-Mendoza • F. Robles-Martinez $\cdot$ L. Herrera-Prats •}

A. Gallardo-Izquierdo • M. D. Bovea

F. J. Colomer-Mendoza , L. Herrera-Prats , A. Gallardo-Izquierdo , M. D. Bovea

Department of Mechanical Engineering and Construction, Universidad Jaume I,

Avda. Vicent Sos Baynat, s/n, 12071 Castellón, Spain

e-mail: fcolomer@emc.uji.es

URL: www.uji.es

F. Robles-Martinez

Unidad Profesional Interdisciplinaria de Biotecnología, Instituto Politécnico Nacional, Mexico, Mexico

\section{Abstract:}

Biodrying is a process that consists in reducing the moisture content and stabilizing organic compounds to obtain a useful product, such as a fuel, or as a previous step to landfilling. This is achieved by using the heat generated in the aerobic fermentation of organic compounds. The main parameters that control the process are aeration, the temperature reached in fermentation, and the initial level of moisture. In this work, the substrate was composed of agricultural harvest and gardening waste from an area in the east of Spain.

The biodrying process was carried out in a greenhouse, where both the heat generated in the fermentation and the heat of the sun were used. In order to promote aeration, two factors were taken into account: one was the capacity of the shredded prunings to act as a bulking agent and the other one was a perforated floor, which allowed air to pass through. An air outlet was installed at the top of the greenhouse to promote the "chimney effect". With this setup, drying times of 12 to 30 days were achieved (depending on the month), together with volume reductions greater than $50 \%$. The time of the trial has been assess when the waste has received 75 $\mathrm{kW} / \mathrm{m}^{2}$. The final waste with a low level of moisture $(7-15 \%)$ had a heating value suitable for use as fuel (around $15,000 \mathrm{~kJ} / \mathrm{kg}$ ).

Key words: biological drying, fermentation; agricultural waste; stabilization. 


\section{Introduction}

Drying of wastes is essential for waste recovery, valorization and landfilling. On the one hand, in order to improve the heating value of wastes it is necessary to minimize its moisture content. On the other hand, in the case of landfilling, simple and effective drying biostabilization prior to landfilling is regarded as a good solution to reduce pollution such as biogas and leachate generation.

In biodrying, the aerobic process focuses on removing water - mainly in the form of vapor-by suitable aeration and the high temperature resulting from degradation of the organic material (Sugni et al. 2005). Biodrying represents an important opportunity for the treatment of mixed waste to consistently raise the dry solids content so that the waste can be disposed of economically in boilers by generating steam and/or power (Choi et al. 2001; Navaee-Ardeh et al. 2006). Biodrying dries the biomass while preserving its calorific value. In particular, according to some authors, biodrying produces an increase in the calorific value of about $30-40 \%$ or more by reducing the water content in the waste. Subsequent mechanical treatments, used to remove low calorie material (metals) and the fine fraction (size $<2 \mathrm{~mm}$ ), make it possible to produce high-calorie fuel $(16,000-17,500 \mathrm{~kJ} / \mathrm{kg}$ ), which is comparable to the calorie content of brown coal (Adani et al. 2002; Sugni et al. 2005; Navaee-Ardeh et al. 2006). The degree of drying, biostability and hygienization during an aerobic biological process can be varied by correct management of the process parameters, the most important of which are temperature, oxygen, airflow rate and moisture content.

Works of Adani et al. (2002) have indicated that appropriate management of the processing parameters (airflow rate and biomass temperatures) could achieve biomass drying in very short times (8-9 days). This biomass can be very heterogeneous, such as sludge, municipal wastes, harvest wastes, etc.

Navaee-Ardeh et al. (2010) dried sludge from pulp and paper mill getting dry solids level (>45\% w/w) in $4-8$ days. Zhang et al. (2008) researched the influence of air flow rate in biodrying of municipal solid wastes achieving $50.5 \%$ of final water content was decreased from the initial $72.0 \%$. The results of Shao et al. (2010) show that, the water content of municipal solid wastes decreased from $73.0 \%$ to $48.3 \%$ after bio-drying (18 days),

On the other hand, the increase of temperature $\left(>55^{\circ} \mathrm{C}\right.$ in some cases $)$ caused by aerobic fermentation reduces the strong odors, and has been proposed as a means of reducing, and even eliminating pathogens present in the livestock waste (Collick et al. 2007). 
All of them analyzed works supply air flow to the reactors in order to dry wastes. In particular, Sugni et al. (2005) suggest that the daily inversion of air-flow eliminates marked temperature differences and leads to a homogeneous final dry municipal solid waste.

So, the main objective in this experiment was to propose an optimal method of biodrying for gardening and harvest waste in a greenhouse by varying the parameters. The presence of a bulking agent, aeration, the remaining time, and temperature and moisture variation are taken into account to achieve this goal (Adani et al. 2002; Sugni et al. 2005; Navaee-Ardeh et al. 2006; Collick et al. 2007; Robles et al. 2010). However, unlike previous mentioned experiments, in the present work is not necessary to provide air flow, but aeration is achieved by means of the chimney effect generated in a greenhouse. So, the authors propose a method for diminishing the amount of moisture in gardening and harvest waste without any external source of energy.

\section{Materials and methods}

The trials were conducted in the Universidad Jaume I located in the town of Castellón, in the east of Spain, $5 \mathrm{~km}$ from the Mediterranean Sea, where the predominant climate is Mediterranean and the environmental humidity is usually high. Coordinates of Castellón are 39 51' 11" N, 0 9' 17" E (UTM 30S 7533404430093 ).

In this work, different types of gardening and harvest waste were dried in a greenhouse that was open at the bottom and at the top in order to allow a chimney effect, which forced aeration of the waste. The greenhouses were built with a wood pallet at the bottom covered with a wire mesh. A PVC pipe structure was attached to the pallet and the whole assembly was covered by transparent LDPE film (Fig. 1). Some trials were carried out without covering in order to compare the greenhouse effect in biodrying.

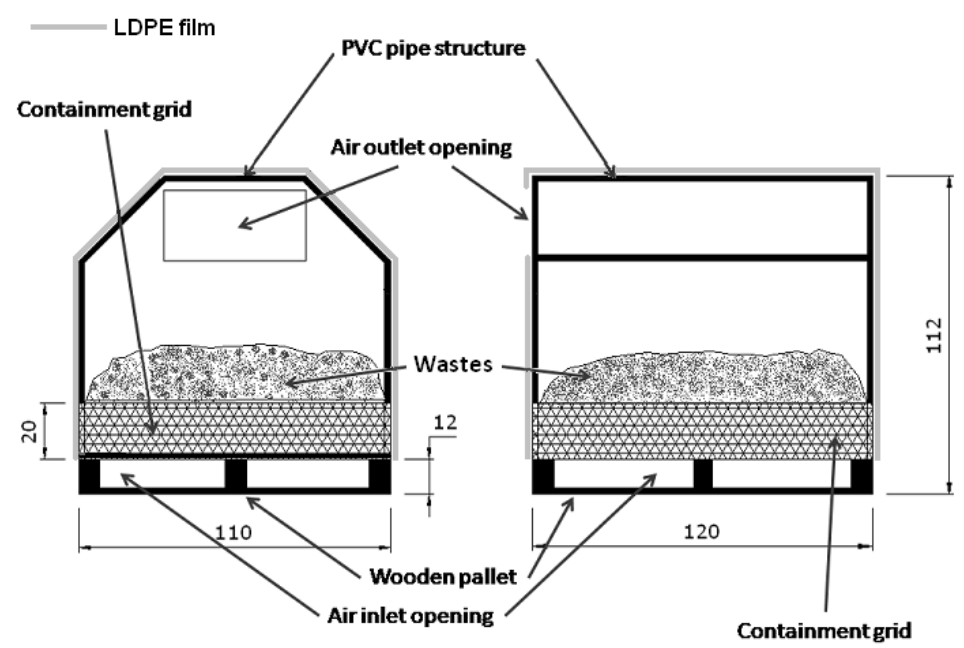

Fig. 1: Setup of the laboratory-scale greenhouses that were constructed (dimensions in centimeters) 
Sampling was performed by quartering different types of waste such as herbaceous waste, wood waste, grass, palm tree leaves, dry phragmites and grape stalks. Finally, $25-40 \mathrm{~kg}$ of the mixture was used as experimental material. Wood waste, palm tree leaves and dry phragmites were crushed into pieces measuring $2-3 \mathrm{~cm}$ and the waste was mixed in order to obtain a homogeneous mass. The initial moisture content of the waste mass was determined following the rules of the ISO 5068-1 standard. The four experiments conducted in this work are outlined in Table 1. The remaining time of different trials was decided according to solar radiation. So, every trials were interrupted when insolation reached $75 \mathrm{~kW} / \mathrm{m}^{2}$ (Fig. 2).

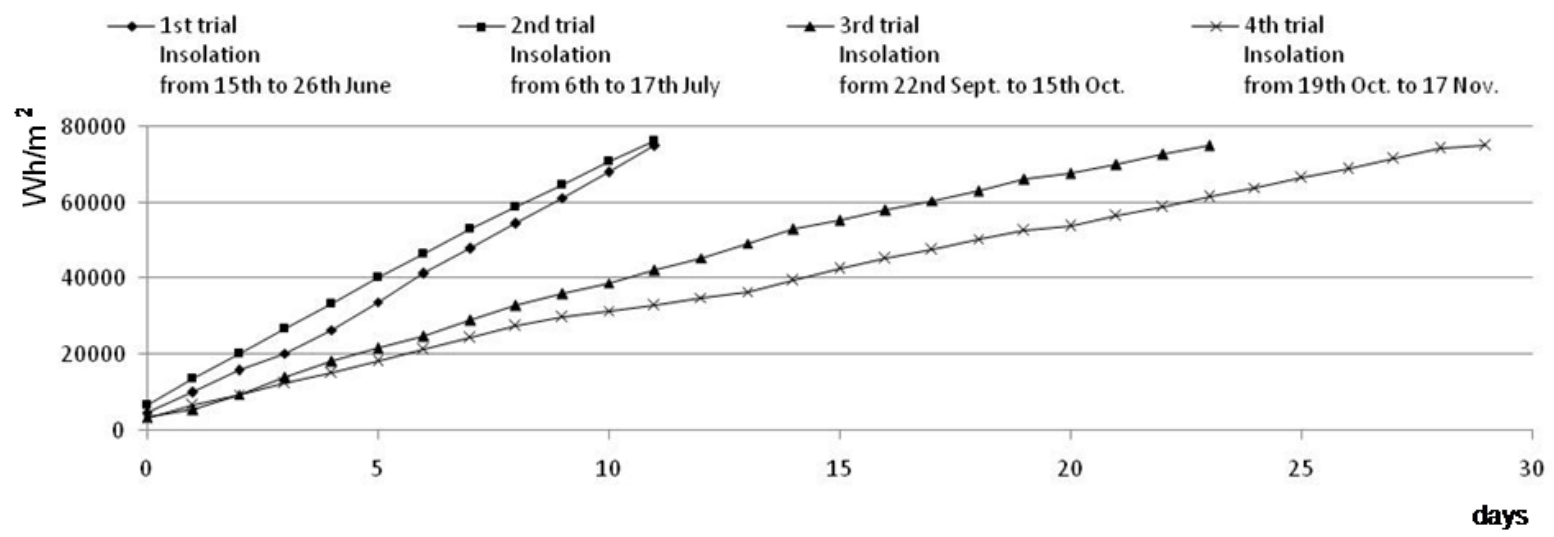

Fig. 2: remaining time and insolation received by greenhouses in trials

Once the waste had been placed in the greenhouse, it was covered by transparent film with an opening to allow heat and humid air to escape (Fig. 1). From then on, data were collected on a daily basis. 


\begin{tabular}{|c|c|c|c|c|c|}
\hline $\begin{array}{c}\text { Trial } \\
\text { (dates and objective) } \\
\text { Insolation: } 75 \mathrm{~kW} / \mathrm{m}^{2}\end{array}$ & $\begin{array}{r}\text { Average } \\
\mathrm{T}\left({ }^{\circ} \mathrm{C}\right) \\
{[\max -} \\
\min ]\end{array}$ & $\begin{array}{r}\text { Average } \\
\text { R.H. (\%) } \\
{[\text { max- }} \\
\text { min] }]\end{array}$ & GH & wastes & $\begin{array}{r}\text { Sample } \\
\text { weight } \\
(\mathrm{kg})\end{array}$ \\
\hline \multirow{5}{*}{$\begin{array}{l}1^{\text {st }} \\
\text { (from } 15^{\text {th }} \text { to } 26^{\text {th }} \text { June, 2010). } \\
12 \text { days. } \\
\text { The influence of a bulking } \\
\text { agent (wood waste) on the } \\
\text { biodrying process was analyzed }\end{array}$} & \multirow{5}{*}{$\begin{array}{c}23 \\
{[16-31]}\end{array}$} & \multirow{5}{*}{$\begin{array}{c}70 \\
{[33-99]}\end{array}$} & GH1 & herbaceous waste & 25 \\
\hline & & & & herbaceous waste $(50 \%)$ & \\
\hline & & & $\mathrm{GH} 2$ & + wood waste and leaves & 33 \\
\hline & & & & $(50 \%)$ & \\
\hline & & & GH3 & grass & 53 \\
\hline \multirow{3}{*}{$\begin{array}{l}2^{\text {nd }} \\
\text { (from } 6^{\text {th }} \text { to } 17^{\text {th }} \text { July, 2010). } 12 \\
\text { days. } \\
\text { The influence of heterogeneity } \\
\text { on the biodrying time was } \\
\text { analyzed }\end{array}$} & \multirow{3}{*}{$\begin{array}{c}27.3 \\
{[23-32]}\end{array}$} & & GH1 & $\begin{array}{c}\text { herbaceous waste }(25 \%) \\
+ \text { wood waste and leaves } \\
(75 \%)\end{array}$ & 41 \\
\hline & & & $\mathrm{GH} 2$ & $\begin{array}{l}\text { herbaceous waste }(15 \%) \\
+ \text { palm tree leaves }(20 \%) \\
+ \text { grass }(65 \%)\end{array}$ & 53.4 \\
\hline & & & GH3 & grass & 55 \\
\hline \multirow{3}{*}{$\begin{array}{l}3^{\text {rd }} \\
\text { (from } 22^{\text {nd }} \text { September to } 15^{\text {th }} \\
\text { October, 2010). } 24 \text { days. } \\
\text { The influence of climatic } \\
\text { conditions on biodrying was } \\
\text { analyzed }\end{array}$} & \multirow{3}{*}{$\begin{array}{c}21.9 \\
{[16-30]}\end{array}$} & \multirow{3}{*}{$\begin{array}{c}79.5 \\
{[37-99]}\end{array}$} & $\begin{array}{c}\text { GH1 } \\
\text { (uncovered) }\end{array}$ & $\begin{array}{l}\text { [herbaceous waste }+ \\
\text { palm tree leaves }+ \text { dry } \\
\text { phragmites] }(30 \%)+\end{array}$ & 40 \\
\hline & & & & grass $(70 \%)$ & \\
\hline & & & $\mathrm{GH} 2$ & $\begin{array}{c}\text { [herbaceous waste }+ \\
\text { palm tree leaves }+ \text { dry } \\
\text { phragmites] }(30 \%)+ \\
\text { grass }(70 \%)\end{array}$ & 40 \\
\hline \multirow{3}{*}{$\begin{array}{c}4^{\text {th }} \\
\text { (from 19th October to } 17 \\
\text { November, 2010). } 30 \text { days. } \\
\text { The greenhouse effect and the } \\
\text { influence of a bulking agent } \\
\text { (grape stalks) on biodrying } \\
\text { were analyzed }\end{array}$} & \multirow{3}{*}{$\begin{array}{c}17.9 \\
{[11-25]}\end{array}$} & \multirow{3}{*}{$\begin{array}{c}66.2 \\
{[24-99]}\end{array}$} & $\begin{array}{c}\mathrm{GH} 1 \\
\text { (uncovered) }\end{array}$ & $\begin{array}{c}50 \% \text { grape stalks+50\% } \\
\text { grass }\end{array}$ & 40 \\
\hline & & & $\mathrm{GH} 2$ & $\begin{array}{l}50 \% \text { grape stalks }+50 \% \\
\text { grass }\end{array}$ & 40 \\
\hline & & & GH3 & $\begin{array}{c}25 \% \text { grape stalks } \\
\text { grass }\end{array}$ & 40 \\
\hline
\end{tabular}

Table 1: Summary of the four biodrying experiments (GH: greenhouse)

\subsection{Data collection}

Environmental temperature and relative humidity were measured from a climatic station situated $2 \mathrm{~km}$ away from our university. Temperature and relative humidity inside the greenhouse were measured with a hygrometer at 12:00 every day. The temperature inside the waste mass was also taken at 12:00 every day and was considered to be the mean of five measurements at different places in the waste mass. The daily level of moisture in the waste was recorded at the same time taking five samples, each weighing $100 \mathrm{~g}$, at different places. The samples were dried in order to determine their moisture content following the ISO 5068-1 standard.

Dried waste was ground in a mill so that $98.75 \%$ of the particles could pass through a $2 \mathrm{~mm}$ sieve. In each of the

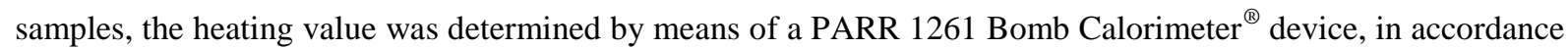
with ISO 1928:1995. Nitrogen content was analyzed using thermal conductivity equipment (LECO FP-528 $8^{\circledR}$ ), carbon and sulfur were measured by infrared spectrometry equipment (LECO SC $144 \mathrm{DR}^{\circledR}$ ) and hydrogen 
content was determined by means of atomic mass spectrometry equipment. Carbon, sulfur and nitrogen content would allow emissions in the incineration process to be estimated in order to prevent the need for gas purification systems. Ash was determined following ISO 1171:1997 specifications. The data shown here are the average of four analyses.

\section{Results}

According to the results of four trials, waste moisture content must be decreased by $87 \%$ in order to raise the heating value by $400 \%$. Furthermore, in this experiment biodrying was achieved with free renewable energies, such as solar power and the heat produced by the aerobic fermentation of waste. The evolution of the environmental temperature and relative humidity in the greenhouse, as well as the moisture in the waste mass in each trial are shown below (Fig. 3, 4, 5 and 6).

In the $1^{\text {st }}$ experiment (Fig. 3) temperature inside the waste mass in $\mathrm{GH} 1$ and $\mathrm{GH} 2$ is lower than in $\mathrm{GH} 3\left(>50^{\circ} \mathrm{C}\right)$ the first six days due to the amount of bulking agent in the waste (GH1 and GH2) that allow the passage of air thorough and therefore, it carries the heat generated in the fermentation by convection. Furthermore, the difference of average environmental temperature $\left(24.7^{\circ} \mathrm{C}\right)$ and average temperature inside the greenhouse $\left(43.5^{\circ} \mathrm{C}\right)$ provokes more homogeneous drying in waste mass. Decreasing humidity is bigger in GH1 and GH2 probably due to the presence of bulking agent.
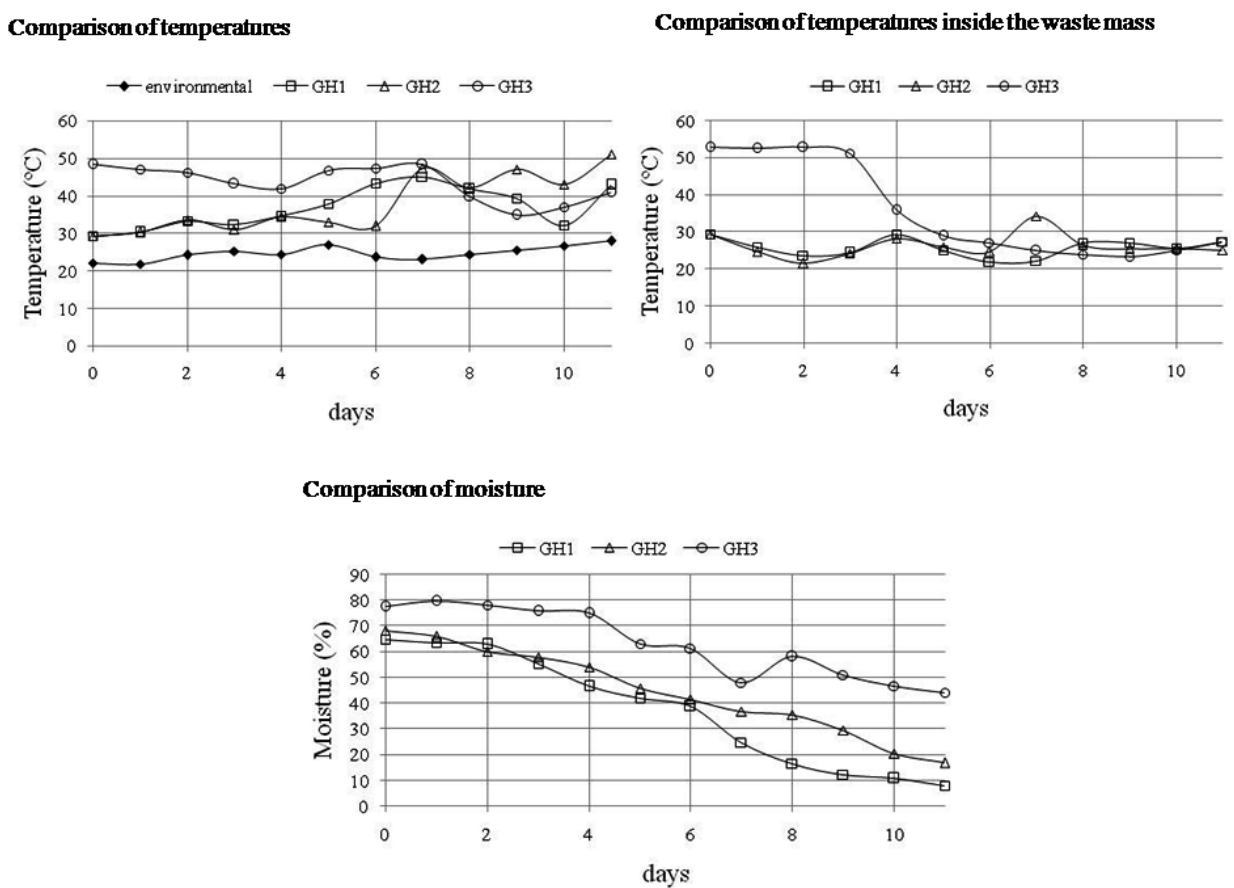

Fig. 3: Data and graphs from three greenhouses in the first experiment 
The explanations of $2^{\text {nd }}$ experiment (Fig. 4) are valid also for experiment 2 but the environmental temperature was slightly higher. However, the weight loss was lower in this period, possibly due to higher average relative humidity.
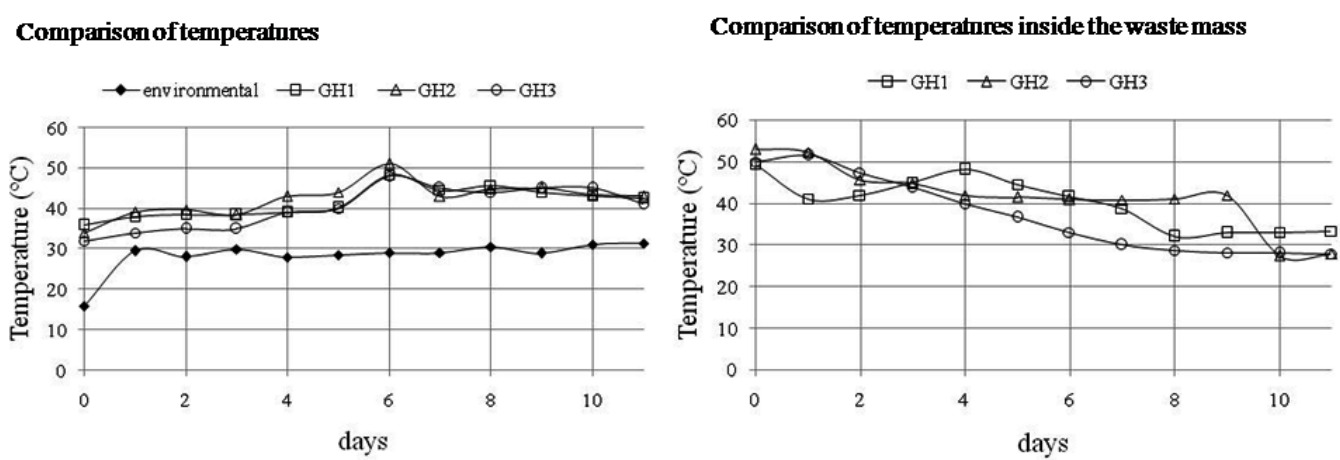

Comparisonofmoisture

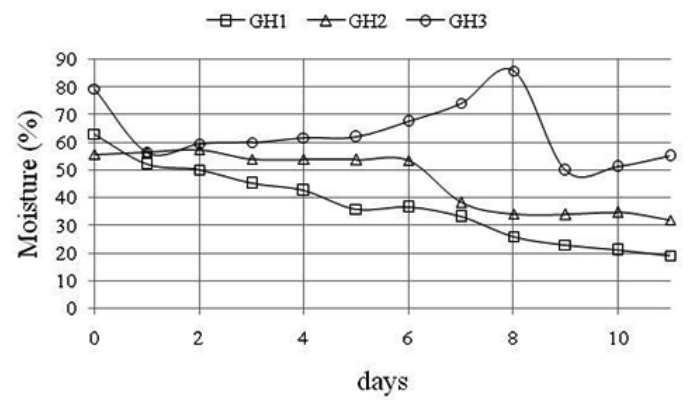

Fig. 4: Data and graphs from three greenhouses in the second experiment

In the $3^{\text {rd }}$ experiment (Fig. 5) temperature inside the waste mass was not different, nevertheless the moisture decreasing in the covered $\mathrm{GH}$ was bigger because the average temperature was $7^{\circ} \mathrm{C}$ higher in the covered $\mathrm{GH}$. Although $18^{\text {th }}$ and $21^{\text {st }}$ days rained, the moisture decreasing was greater in the GH covered on dry days too. 

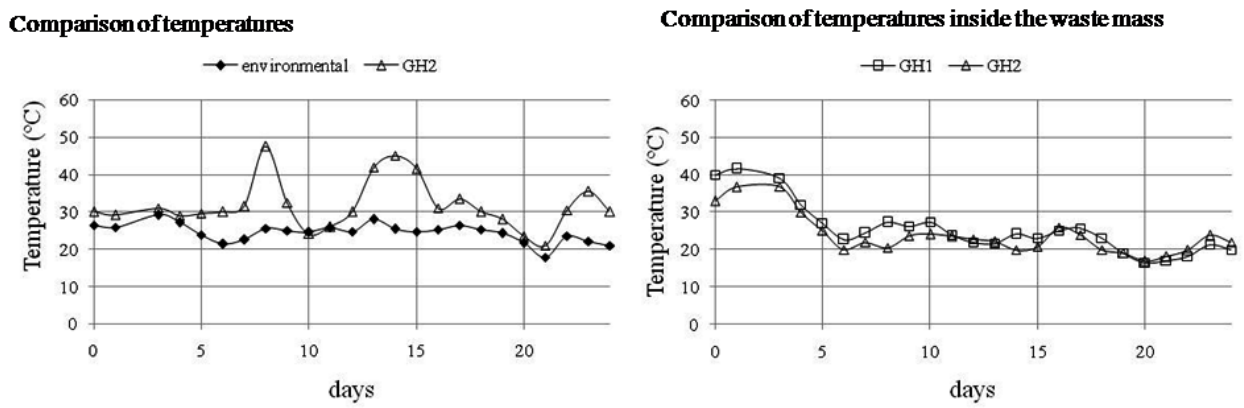

Comparisonofmoisture

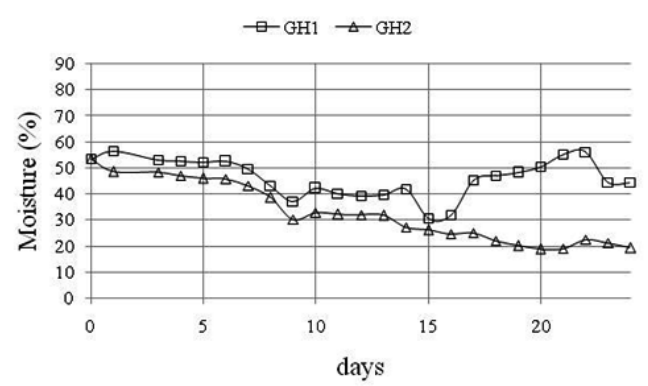

Fig. 5: Data and graphs from two greenhouses in the third experiment

In the $4^{\text {th }}$ experiment (Fig. 6 ) the temperature of waste mass is similar in the three GH (the first 6 days it surpass the environmental temperature $\left(20.2^{\circ} \mathrm{C}\right)$ ) but drying is more efficient in $\mathrm{GH} 2$ due to better aeration in the waste mass and the transparent film covering.
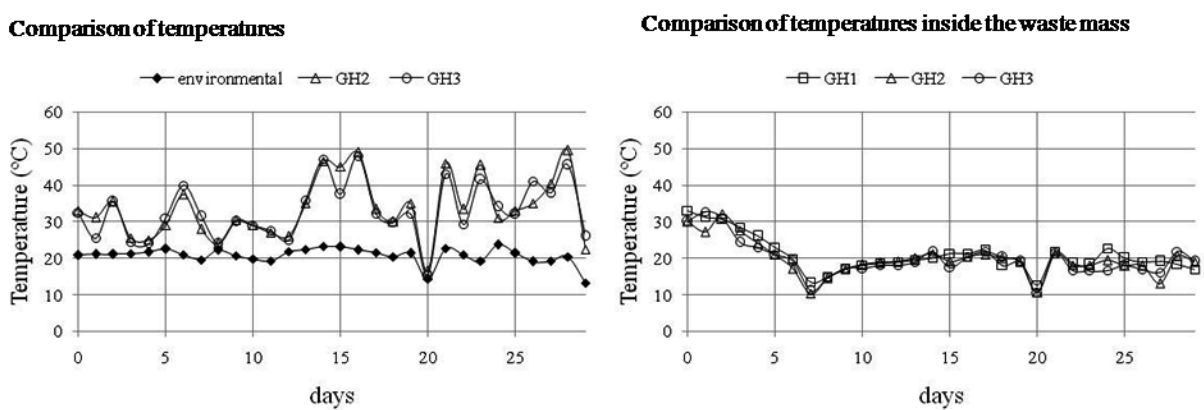

Comparison of moisture

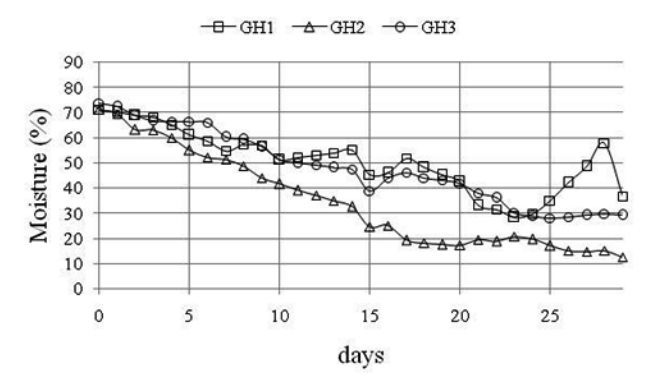

Fig. 6: Data and graphs from three greenhouses in the fourth experiment 
On the other hand, in accordance with item 2.1, data on the lower heating value (LHV) of greenhouses were also collected. Obviously, the LHV increases as moisture decreases. Nevertheless, the LHV (dry mass) at the end of the experiments did not change in any statistically significant way from the values recorded when they began. Thus, the graphs in Fig. 7 were plotted to show the moisture content of the sample. Summarized data about the initial LHV and final LHV can be seen in Table 2. Data concerning ash, carbon, nitrogen and sulfur content are also shown in Table 2.
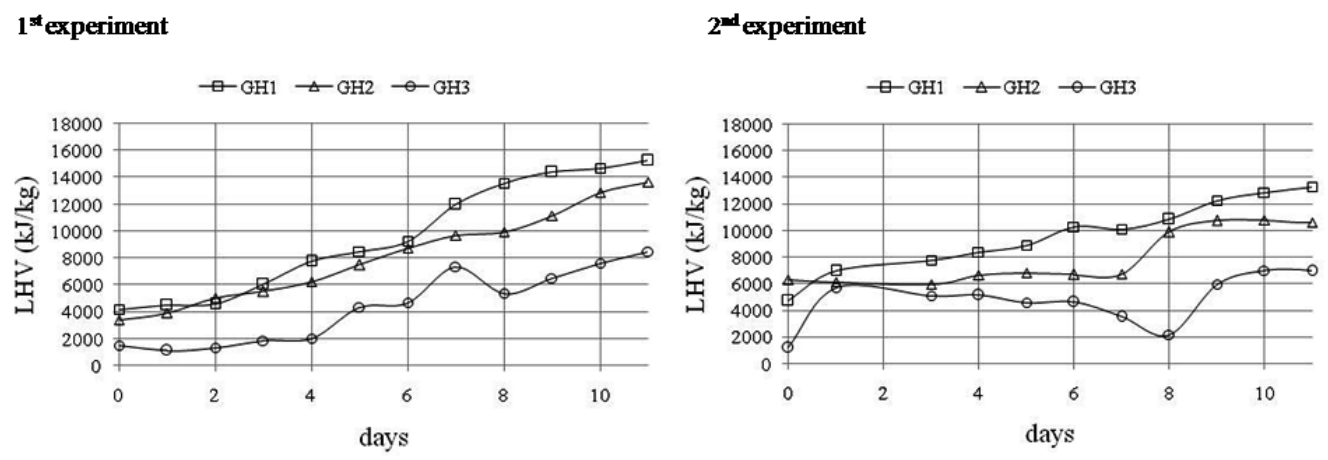

$3^{\text {rd }}$ experiment

4*eriment
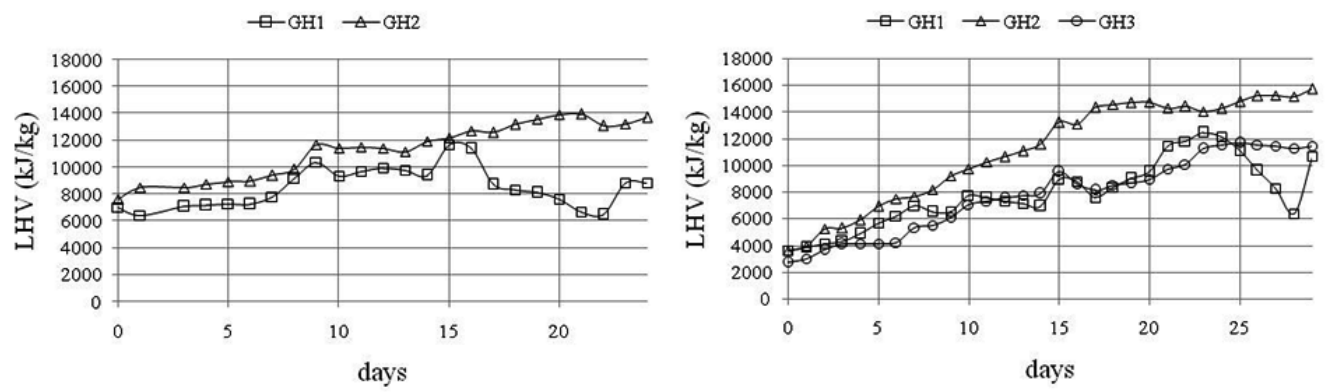

Figure 7: Graphs of the evolution of LHV $(\mathrm{kJ} / \mathrm{kg})$ from four biodrying process trials

Nevertheless, the volume of water evaporated was not the same from one experiment to another, and the performance of different experiments was not the same either. Table 3 represents the efficiency of evaporation, and weight loss according to different types of waste. 
Table 2: Results of the analyses (dry mass) of sulfur $(\mathrm{S})$, carbon $(\mathrm{C})$, nitrogen $(\mathrm{N})$, and ash. Initial and final moisture, initial LHV, final LHV, increase in LHV at the end of the biodrying process in different greenhouses $(\mathrm{GH})$ in different experiments

\begin{tabular}{cccccccccc}
\hline Exp. & $\mathrm{GH}$ & $\begin{array}{c}\mathrm{S} \\
(\%)\end{array}$ & $\mathrm{C}(\%)$ & $\begin{array}{c}\mathrm{N} \\
(\%)\end{array}$ & $\begin{array}{c}\text { ash } \\
(\%)\end{array}$ & $\begin{array}{c}\text { Initial/ final } \\
\text { moisture }(\%)\end{array}$ & $\begin{array}{c}\text { Initial } \\
\text { LHV } \\
(\mathrm{kJ} / \mathrm{kg})\end{array}$ & $\begin{array}{c}\text { Final } \\
\text { LHV } \\
(\mathrm{kJ} / \mathrm{kg})\end{array}$ & $\begin{array}{c}\text { Increase } \\
\text { LHV } \\
(\%)\end{array}$ \\
\hline \multirow{2}{*}{$1^{\text {st }}$} & $\mathrm{GH} 1$ & 0.21 & 32.65 & 1.84 & 9.32 & $64.8 / 7.9$ & 4458.7 & 15257.5 & 263 \\
& $\mathrm{GH} 2$ & 0.31 & 32.78 & 2.33 & 7.90 & $68.3 / 16.8$ & 3427.9 & 13646.7 & 298 \\
& $\mathrm{GH} 3$ & 0.45 & 29.39 & 3.52 & 13.85 & $77.5 / 42.2$ & 1535.7 & 8503.2 & 453 \\
\hline \multirow{2}{*}{$2^{\text {nd }}$} & $\mathrm{GH} 1$ & 0.21 & 34.94 & 2.81 & 8.50 & $62.8 / 21.0$ & 4737.1 & 13284.4 & 180 \\
& $\mathrm{GH} 2$ & 0.30 & 33.15 & 2.20 & 9.21 & $55.6 / 34.6$ & 6332.2 & 10628.5 & 68 \\
& $\mathrm{GH} 3$ & 0.56 & 33.89 & 3.65 & 12.74 & $79.3 / 50.0$ & 1188.2 & 6964.8 & 486 \\
\hline $3^{\text {rd }}$ & $\mathrm{GH} 1$ & 0.32 & 33.81 & 1.75 & 6.82 & $53.3 / 19.2$ & 7581.3 & 13665.6 & 80 \\
\hline \multirow{2}{*}{$4^{\text {th }}$} & $\mathrm{GH} 2$ & 0.21 & 35.90 & 1.59 & 8.40 & $71.0 / 12.5$ & 3609.6 & 15688.7 & 322 \\
& $\mathrm{GH} 3$ & 0.24 & 33.48 & 2.04 & 10.35 & $73.6 / 29.1$ & 2691.2 & 11425.5 & 325 \\
\hline
\end{tabular}

Table 3: Water evaporated and weight loss in different experiments

\begin{tabular}{cccc}
\hline $\begin{array}{c}\text { Experiment } \\
\text { (days) }\end{array}$ & $\mathrm{GH}$ & $\begin{array}{c}\text { water evaporated } \\
(\%)\end{array}$ & weight loss (\%) \\
\hline $1^{\text {st }}$ & $\mathrm{GH} 1$ & 95.3 & 61.7 \\
12 days & $\mathrm{GH} 2$ & 90.6 & 61.9 \\
& $\mathrm{GH} 3$ & 78.8 & 61.1 \\
\hline $2^{\text {nd }}$ & $\mathrm{GH} 1$ & 84.3 & 52.9 \\
12 days & $\mathrm{GH} 2$ & 57.6 & 32 \\
\hline $3^{\text {rd }}$ & $\mathrm{GH} 3$ & 73.9 & 58.6 \\
25 days & $\mathrm{GH} 2$ & 79.2 & 42.2 \\
\hline \multirow{2}{*}{$4^{\text {th }}$} & $\mathrm{GH} 1$ & 76.3 & 54.2 \\
30 days & (uncovered) & 94.2 & 66.9 \\
& $\mathrm{GH} 2$ & 85.3 & 62.9 \\
\hline
\end{tabular}

\section{Discussion}

In biodrying, the main drying mechanism is convective evaporation, using heat from the aerobic biodegradation of waste components and facilitated by the mechanically supported airflow.

In this experiment gardening and harvest wastes have similar initial moisture than other types of wastes as municipal solid wastes (66.7 -75\%) (Adani et al. 2002; Zhang et al. 2008; Zhang et al. 2009), or pulp and paper mixed sludges (75\%) (Navaee-Ardeh 2006).

A comparison between biodrying a single type of waste or a mixture showed that different textures, materials and sizes influence biodrying time. Thus, waste masses with different materials (herbaceous waste, wood waste and leaves) reach lower levels of moisture than grass alone. This must be due to the fact that there are materials that cause a bulking effect and air can therefore go through the waste mass and dry it by convection. Although environmental humidity is high in the town of Castellón itself (Table 1), moisture fell by $87 \%$ in GH1 in the 1st experiment. In the 2nd experiment the moisture in grass alone fell by $37 \%$ and grass mixed with herbaceous 
waste and palm tree leaves fell by $38 \%$ therefore is not a significant difference. Nevertheless, the more bulking material there is, the more efficient the biodrying process is, as shown in the results of the 4th experiment $(\mathrm{GH} 2$ and GH3). The moisture in a mixture containing $50 \%$ grape stalks plus $50 \%$ grass fells by $82 \%$ and a mixture with $25 \%$ grape stalks plus $75 \%$ grass fells by $60 \%$. Hence, homogeneous waste like grass is dried in less time if a bulking agent is mixed with it.

On the other hand, the transparent film of the greenhouses retains the heat provided by fermentation and the sun, and therefore covered greenhouses provided less moisture than uncovered ones. Moisture therefore fell by $64 \%$ in a covered GH and the humidity did not decrease in an uncovered GH (experiment 3). The same thing happened in experiment 4: moisture fell by $82 \%$ in a covered GH and $48 \%$ in an uncovered GH. Nevertheless, experiences have been made in different months and therefore, depending on the environmental temperature and humidity and number of sunshine hours of the month, the time of biodrying varies because time of insolation varies too.

Thus, it was observed that fermentation and the sun provide the energy needed to dry the waste. In this work, part of the water in the waste was evaporated, levels of moisture in waste below $15 \%$ being reached in some cases. In their works, Velis et al. (2009) reported that commercial process cycles are completed within 7-15 days, with mostly loses of water $25-30 \% \mathrm{w} / \mathrm{w}$, leading to moisture contents of $<20 \% \mathrm{w} / \mathrm{w}$.

According to the data in Table 3, the $1^{\text {st }}$ experiment, GH1 was the most efficient. Nevertheless, weight loss was very similar in the three GH. The same thing happened in the $4^{\text {th }}$ experiment. However, in the $2^{\text {nd }}$ experiment, the GH with grass alone was the one that achieved the biggest weight loss, and the most efficient was GH1, with a mixture of different kinds of waste.

Obviously, covered greenhouses are more efficient than uncovered ones $\left(3^{\text {rd }}\right.$ and $4^{\text {th }}$ experiments) because drying is more homogeneous due to internal and external heat. In the case of the $4^{\text {th }}$, the addition of a larger amount of bulking material, such as grape stalks, had a favorable effect.

Finally, the moisture in the waste after the biodrying process was reasonably low in some cases. Gardening and harvest waste with this percentage of moisture (less than 15\%) can be incinerated in an incineration plant to allow them to be used for energy recovery. In fact, in this sort of plant an LHV above 8,500-10,000 kJ/kg is recommended, which is a value that was accomplished in the majority of cases (Table 2). These values are similar to other works as dried municipal solid wastes $(8,200-13,813 \mathrm{~kJ} / \mathrm{kg}$ ) (Zhang et al. 2009; Sugni et al. 2005), On the other hand, the levels of S, C and N were not high enough to cause problems due to atmospheric emissions. Furthermore, the volume of ash after incineration was not very high 
Therefore, aerobic fermentation, heat from the sun and chimney effect provides an increase in temperature that promotes the evaporation of the water content in the waste. On the other hand, a transparent film retains the, thereby also increasing the temperature. The causes air to rise through the waste mass, which drags part of the moisture out with it by convection.

This method is different than other works of biodrying because they uses an external airflow to drag moisture (Sugni et al. 2005; Navaee-Ardeh et al. 2006; Zhang et al. 2008; Zhang et al. 2009; Velis et al. 2009; NavaeeArdeh 2010).

So, these are both free and clean sources of energy that allowed the moisture in the waste to be reduced to acceptable levels in a reasonably short amount of time without any bad smells or toxic gases. Nevertheless, according on the month and the season (environmental temperature and humidity) the time for biodrying can vary. Loss of moisture results in a reduction of weight and volume above $50-60 \%$, and therefore transport costs are lower for dry waste. Furthermore, biodrying results an acceptable fuel for furnaces.

In sum, biodrying in greenhouses would be a cheap and easy way to dry gardening and harvest waste, and its use could be applied in settings such as large gardens, on farms or on university campuses, for example. The only requirement would be an appropriate piece of land on which to install the greenhouses.

\section{Acknowledges}

The authors are grateful to the Spanish Ministry of Science and Innovation for funding for this study (Project ACI2009-0993) in the program “Convocatoria de Ayudas del Programa Nacional de Internacionalización de la I+D. Subprograma de Fomento de la Cooperación Científica Internacional (ACI-PROMOCIONA)". We also wish to thank to our colleague Ms Sara Romero because for her help in the works.

\section{References}

Adani, F., Baido, D., Calcaterra, E., \& Genevini, P. (2002). The influence of biomass temperature on biostabilization-biodrying of municipal solid waste. Biorresource Technol, 83, 173-179.

Choi, H. L., Richard, T. L., \& Ahn, H. K. (2001). Composting high moisture materials: Biodrying poultry manure in a sequentially fed reactor. Compost Science \& Utilization, 9, 303-311.

Collick, A.S., Inglish, S., Wright, P., Steenhuis, T.S., \& Bowman D.D. (2007). Inactivation of Ascaris suum in a Biodrying Compost System. J Environ Qual, 36, 1528-1533. 
ISO 1928-1995. Solid mineral fuels - Determination of gross calorific value by the bomb calorimetric method, and calculation of net calorific value.

ISO 1171:1997, Solid mineral fuels - Determination of ash

ISO 5068-1:2007, Brown coals and lignites - Determination of moisture content - Part 1: Indirect gravimetric method for total moisture.

Navaee-Ardeh, S., Bertrand, F., \& Stuart, P.R. (2006). Emerging biodrying technology for the drying of pulp and paper mixed sludges. Dry Technol, 24, 863-876.

Navaee-Ardeh, S., Bertrand, F., \& Stuart, P.R. (2010). Key variables analysis of a novel continuous biodrying process for drying mixed sludge. Bioresource Technol, 101, 3379-3387.

Robles, F., Ramírez, I., Piña, A.B., \& Colomer, F.J. (2010). Efecto de la adición de agentes estructurantes a residuos hortícolas en tratamientos aeróbicos. Ingeniería Agrícola y Biosistemas, 2 (1), 45-51.

Sugni, M., Calcaterra, E., \& Adani, F. (2005). Biostabilization-biodrying of municipal solid waste by inverting air-flow. Bioresource Technol, 96, 1331-1337.

Velis, C.A., Longhurst, P.J., Drew, G.H., Smith, R. \& Pollard, S.T.J. (2009). Biodrying for mechanical-

biological treatment of wastes: A review of process science and engineering. Bioresource Technol, 100, $2747-$ 2752.

Zhang, D., He, P., Shao, L., Jin, T., Han, J. (2008). Biodrying of municipal solid waste with high water content by combined hydrolytic-aerobic technology. J Env Sci, 20, 1534-1540

Zhang, D., He P., Shao L. (2009). Potential gases emissions from the combustion of municipal solid waste by bio-drying. J Hazard Mater, 168, 1497-1503. 